\title{
Before and After the Economic Growth, Regulatory Relief and Consumer Protection Act of 2018
}

\author{
W. Terry Dancer \\ Arkansas State University \\ Dwayne Powell \\ Arkansas State University
}

The Dodd-Frank Wall Street Reform and Consumer Protection Act became law on July 21, 2010. The law was enacted to provide at least a modicum of regulation to the financial industry following the recession of 2008, leading to what some called the worst economic downturn in the United States Economy since the Great Depression. On May 24, 2018, President Trump signed S. 2155, The Economic Growth, regulatory relief, and Consumer Protection Act (the Relief Act). Many believe this new law put an end to Dodd-Frank. Others believe the new law did nothing to repeal and replace Dodd-Frank. In a prior study, the authors asked community bankers, "How will your day-to-day activities change if Dodd-Frank is repealed?" This paper follows up with a survey of community bankers to determine if S. 2155 had the expected results. This study finds that the Relief Act did not have the anticipated impact.

Keywords: banking regulations, consumer protection, Dodd-Frank

\section{INTRODUCTION}

The genesis for the Economic Growth, Regulatory Relief, and Consumer Protection Act of 2018 ("the Relief Act") occurred on July 21, 2010, with the Dodd-Frank Wall Street Reform and Consumer Protection Act ("Dodd-Frank"). Dodd-Frank was passed following the financial recession of the late 2000s and involved 845 pages and 225 new regulations across 11 agencies (Acharya \& Richardson, 2012), resulting in a significant increase in non-interest expense (Hogan \& Burns, 2019). Hogan \& Burns (2019) estimate that annual non-interest expenses increased between $\$ 58.7$ billion and $\$ 86.1$ billion following the enactment of Dodd-Frank. In addition to the billions of dollars spent on implementing Dodd-Frank, the American Action Forum (AAF) estimated that Dodd-Frank resulted in approximately 73 million hours of paperwork (Wyatt, 2016). Despite the billions of dollars spent and millions of hours worked, the law resulted in a $14.5 \%$ decline in revolving consumer credit (Milloy, 2016). Wyatt (2016) suggests that Dodd-Frank harmed the US markets by increasing complexity and turmoil for consumers and banks. These impacts are reported to be more significant for community banks, "...it has created onerous requirements that have made it especially difficult for smaller financial institutions and their customers (Anderson, 2016)."

Small community banks make up a vital part of the economy and rely on a relationship model, relying less on "hard data" (financial models) and more on "soft data" (relationships) (Hanauer et al., 2021; Schorgl, 2018). These community banks issue 48.1 percent of small-business loans, 15.7 percent of home loans, 42.8 
percent of farmland loans, 43.8 percent of farm loans, and 34.7 percent of commercial real estate loans; therefore, the passage of the Dodd-Frank Act has unquestionably increased the number of Americans who are underbanked (Marsh \& Norman, 2013; Schorgl, 2018). Community banks decreased 35\% from 6,530 in 2010 to 4,277 in 2020 (Hanauer et al., 2021). Some suggest that the significant decrease in community banks following the passage of Dodd-Frank was a direct result of the increase in regulation and compliance costs as a result of Dodd-Frank (Schorgl, 2018).

New regulations brought upon by the Dodd-Frank Act make it incredibly difficult for community banks to keep up with compliance costs and lessen their ability to earn rates of return that can cover these costs. As a result, this has forced many smaller banks to consolidate with larger banks and increased the competitive advantage larger banks have in comparison to smaller banks (Schorgl, 2018, p. 5).

By the late 2010s, however, many bankers, consumers, regulators, and politicians resolved that the unintended consequences of Dodd-Frank were an unnecessary compliance burden, needless legal requirements, and high compliance costs for community banks (Heitkamp, 2017; Kress \& Turk, 2019; Lux \& Greene, 2016). In 2018, policymakers from both major political parties agreed that for community banks to remain competitive, a rollback of Dodd-Frank requirements was necessary and passed the Relief Act easing capital requirements, loosening liquidity rules, and relaxing supervisory oversight of community banks (Klein, 2018; Kress \& Turk, 2019). Industry groups and regulators supported the Relief Act (Comptroller of the Currency Lauds Progress Toward Meaningful Regulatory Reform, 2017; ICBA Supports Senate Community Bank Regulatory Relief Agreement, 2017)

The Relief Act is designed to provide regulatory and compliance relief to community banks allowing them to compete more effectively. Following the enactment of the Relief Act, some were quick to praise the legislation, while others quickly pointed out a lack of substance in the legislation. Some think it went too far, some thought it did not go far enough, and some believe the new law did nothing to change DoddFrank. The Relief Act seeks to differentiate how the Federal Government will regulate banks depending on size (Dexheimer, 2018; In Historical Moment for CUs, Trump Signs S. 2155, 2018; Klein, 2018; Michel, 2018).

Given the conflicting reactions to the Relief Act, we conducted a qualitative study of community bankers to determine whether it provided meaningful regulatory relief that resulted in a significant change in their day-to-day activities. This study is a follow-up to a study we conducted prior to enacting the Relief Act (Dancer \& Powell, 2018).

\section{DESCRIPTION OF THE STUDY}

In our prior study, anticipating the passage of the Relief Act, we asked community bankers the following question, "How will your day-to-day activities change if Dodd-Frank is repealed (Dancer \& Powell, 2018)?" In this study, we asked community bankers, "How has this law affected your day-to-day activities?" and we compared the results of the two surveys. The community bankers surveyed in each study were a convenience sample from our network of business acquaintances. Both surveys were conducted using the same network of associates; however, the respondents were not identical. Ten community bankers responded to the first survey, and fifteen responded to the second survey. We compared the comments from the two surveys to determine if the Relief Act had the anticipated results. In the following paragraphs, we present a summary of the results from each survey, and then we compare the results of the second survey to the results of the first survey.

\section{Survey \#1}

In anticipation of the actions by the House, the Senate, and the President and the continued debate over Dodd-Frank, we surveyed individuals employed by community banks, and we asked, "How will your day- 
to-day activities change if Dodd-Frank is repealed?" In addition, we asked respondents to provide the following demographic information:

1. The number of years of experience in a community bank.

2. Position/title

3. Size of institution

The respondents ranged from fourteen to forty-five years of community banking experience. Respondents' positions included officers (VP and up), commercial loan officer, market president, credit manager, compliance officer, and CEO. The size of the represented institutions ranged from $\$ 230$ million to $\$ 1.7$ billion in assets. These respondents represent a broad range of experience, positions, and institution size within the community banking context.

The actual responses to the survey are included in Appendix A. In summary, respondents were generally optimistic about the anticipated outcome of the Relief Act. Many comments focused on the anticipated opportunity to utilize fewer resources to meet compliance obligations and looked forward to the opportunity to utilize these resources to serve their customers and community better (Dancer \& Powell, 2018).

Relevant comments include the following:

- "...more efficient operation...."

- "...less time on regulations...."

- "...focus our energy and resources on the things that make a community bank a community bank."

- "...less time monitoring compliance...."

- "...more time serving our customer base...."

- “...more efficient...."

- "...more nimble...."

- "...more responsive...."

\section{Survey \#2}

Following the enactment of the Relief Act, we surveyed individuals employed by community banks, and we asked, "How has the Relief Act affected your day-to-day activities?" In addition, we asked respondents to provide the following demographic information:

1. The number of years of experience in a community bank.

2. Position/title

3. Size of institution

The respondents ranged from four to fifty years of community banking experience. Respondents' positions included officers (VP and up), mortgage loan officer, chief credit officer, controller, business development officer, appraiser, CEO, commercial credit underwriter, and chairman. The size of the institution ranged from $\$ 100$ million to $\$ 28$ billion in assets. These respondents represented a broad range of experience, positions, and institution size within the community bank context.

The actual responses to the survey are included in Appendix B. In summary, respondents noted little impact on their day-to-day activities. One noted, "It improved our ability to provide more efficient service to our customers." A couple mentioned that the Relief Act streamlined the appraisal process and saved the bank and its customers money. Another respondent stated, "The aforementioned Act eliminated supervisory stress testing for institutions under $\$ 100$ billion." Overall, based on the respondents' comments, it appears that the Relief Act did not have the anticipated impact. In the first survey (Dancer \& Powell, 2018), respondents were optimistic that the Relief Act would result in a significant change to their day-to-day activities; however, after the enactment of the Relief Act, most responded that it had little impact on their day-to-day activities.

Relevant comments include the following:

- "Has not affected...."

- "Did not have a significant impact...." 


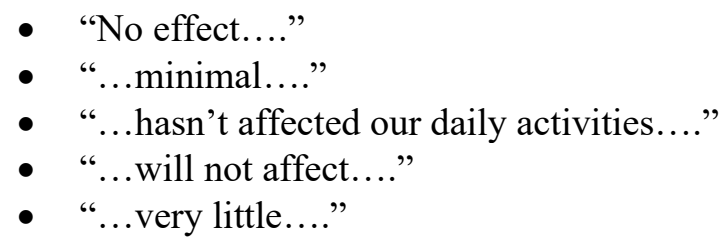

\section{SUMMARY}

The Dodd-Frank Act passed in 2010 was enacted to regulate financial markets in such a way as to prevent the economic meltdown that happened in 2007/2008 from ever happening again. The Economic Growth Regulatory Relief and Consumer Protection Act of 2018 attempted to roll back many of the regulations put in place by Dodd-Frank.

Proponents of the 2018 act believed Dodd-Frank went too far in regulating financial markets and artificially placed an undue burden on the ability of the market to function properly. Opponents of the 2018 Act believed the regulations implemented by Dodd-Frank were necessary to prevent another financial debacle like 2007/2008.

A survey of financial market managers before the Relief Act and after the Relief Act compared perceptions to reality. The results found that reality did not meet expectations.

Financial market managers were asked before the Relief Act, "How will your day-to-day activities change if Dodd-Frank is repealed?" The managers noted: more efficient operations; more time banking less time trying to comply; spend less time on regulation; we could focus our energy and resources; spend less time monitoring compliance; I anticipate less emphasis each day on compliance; We would spend more time serving customers; Allow us to devote more time and resources to serving customers; day to day activities would be more efficient; A rollback of the burden of Dodd-Frank would allow me to be more responsive to customer needs.

Financial market managers were then asked after the 2018 Act passed, "How has this law affected your day-to-day activities?" The managers noted: Not affected my day-to-day activities; Did not have a significant impact; No effect; Impacts were very minimal; not affected at this point; eliminated some supervisory stress; will not affect; very little; improved our ability to service customers.

The before and after results indicate that the expectations did not match reality. While most believed significant changes would result before the Relief Act, once reality set in, most financial managers noted the Relief Act had no impact, minor impact, or minimal impact.

\section{REFERENCES}

Acharya, V.V., \& Richardson, M. (2012). Implications of the Dodd-Frank Act*. Annual Review of Financial Economics, 4(1), 1-38. https://doi.org/10.1146/annurev-financial-030912-140516

Anderson, J.C. (2016, November 21). Barney Frank warns against hasty repeal of Dodd-Frank Act. Press Herald. Retrieved from https://www.pressherald.com/2016/11/20/barney-frank-others-cautionabout-hasty-repeal-of-dodd-frank/

CUInsight. (2018, May 14). In historical moment for CUs, Trump signs S. 2155. Retrieved from https://www.cuinsight.com/press-release/in-historical-moment-for-cus-trump-signs-s-2155

Dancer, W.T., \& Powell, D. (2018). Dodd-Frank repeal: assessing the change in the day-to-day activities of financial institutions. Journal of Accounting \& Finance, 18(7), 50-55.

Dexheimer, E. (2018, May 23). Biggest Rollback of Bank Rules Since Dodd-Frank Clears House. BloombergQuint. Retrieved from https://www.bloombergquint.com/politics/biggest-bank-rulerollback-since-dodd-frank-is-approved-by-house

Hanauer, M., Lytle, B., Summers, C., \& Ziadeh, S. (2021). Community Banks' Ongoing Role in the US Economy. The Federal Reserve Bank of Kansas City Economic Review. https://doi.org/10.18651/ER/v106n2HanauerLytleSummersZiadeh 
Heitkamp, S. (2017, June 27). Political foes agree: Small banks pounded by Dodd-Frank. The Hill. Retrieved from https://thehill.com/blogs/pundits-blog/finance/339693-helping-small-banks-issomething-we-can-all-agree-on

Hogan, T.L., \& Burns, S. (2019). Has Dodd-Frank affected bank expenses? Journal of Regulatory Economics, 55(2), 214-236. https://doi.org/10.1007/s11149-019-09379-8

ICBA. (2017, November 13). ICBA Supports Senate Community Bank Regulatory Relief Agreement. Retrieved from https://perma.cc/T9RP-FL55

Klein, A. (2018, March 4). Bipartisanship in banking is back. Retrieved from https://www.brookings.edu/research/bipartisanship-in-banking-is-back/

Kress, J.C., \& Turk, M.C. (2019). Too Many to Fail: Against Community Bank Deregulation. SSRN Electronic Journal. https://doi.org/10.2139/ssrn.3503692

Lux, M., \& Greene, R. (2016, April 14). Dodd-Frank Is Hurting Community Banks. New York Times. Retrieved from https://www.nytimes.com/roomfordebate/2016/04/14/has-dodd-frank-eliminatedthe-dangers-in-the-banking-system/dodd-frank-is-hurting-community-banks

Marsh, T.D., \& Norman, J.W. (2013). The Impact of Dodd-Frank on Community Banks. SSRN Electronic Journal. https://doi.org/10.2139/ssrn.2302392

Michel, N. (2018, March 14). Crapo Bill Helps Smaller Banks, Highlights Problems With Bank Holding Companies. The Heritage Foundation. Retrieved from https://www.heritage.org/governmentregulation/commentary/crapo-bill-helps-smaller-banks-highlights-problems-bank-holding

Milloy, M. (2016, July 21). Oh, The Places You'll Go: Dodd-Frank Edition. AAF. Retrieved from https://www.americanactionforum.org/insight/oh-places-youll-go-dodd-frank-edition/

Office of the Comptroller of the Currency. (2017, December 5). Comptroller of the Currency Lauds Progress Toward Meaningful Regulatory Reform (All Districts, Central District, HQ, International, Northeastern District, Southern District, USA, Western District). Retrieved from https://www.occ.treas.gov/news-issuances/news-releases/2017/nr-occ-2017-145.html

Schorgl, M. (2018). The Dodd-Frank Act and its Impact on Community Bank Mortgage Lending.

Wyatt, B. (2016, July 27). Six Years Later Dodd-Frank Has Cost Almost $\$ 40$ Billion - Illinois Manufacturers' Association. Retrieved from https://ima-net.org/six-years-later-dodd-frank-hascost-almost-40-billion/ 


\section{APPENDIX A: SURVEY \#1 RESULTS}

\begin{tabular}{|c|c|c|c|}
\hline Position/Title & Years & Size & Response \\
\hline CEO & 30 & $\$ 230$ million & $\begin{array}{l}\text { Our changes would be a more efficient operation that } \\
\text { would spend more time banking and less time trying to } \\
\text { comply. I think most bankers would tell you that we are } \\
\text { banking defensively so as to try to avoid examiner } \\
\text { criticism. }\end{array}$ \\
\hline Chairman & 45 & $\$ 750$ million & $\begin{array}{l}\text { I would have more time to work with loan officers to } \\
\text { develop new loan relationships. I would spend less time } \\
\text { on regulations that do not benefit the customer and more } \\
\text { time on developing customer relationships. }\end{array}$ \\
\hline CEO & 25 & $\$ 232$ million & $\begin{array}{l}\text { I believe we could focus our energy and resources on the } \\
\text { things that make a community bank a community bank. In } \\
\text { "Smalltown, USA" we know our customers and want to } \\
\text { help families with lending needs and help small businesses } \\
\text { grow and become a vital part of our community. }\end{array}$ \\
\hline CEO & 23 & $\$ 280$ million & $\begin{array}{l}\text { It would allow me to spend more time in the community } \\
\text { serving and assisting customers and prospects which I } \\
\text { believe, in turn, would allow our bank and community to } \\
\text { be more successful and prosperous. I would spend less } \\
\text { time monitoring compliance and trying to figure out how } \\
\text { to serve customers within the parameters of over- } \\
\text { burdensome regulations. } \\
\text { Resources currently committed to compliance would be } \\
\text { reallocated to customer products and services that would } \\
\text { grow both our bank and the communities we serve. }\end{array}$ \\
\hline CEO & 35 & $\$ 239$ million & $\begin{array}{l}\text { Yes, it would change day to day activity, but I find it } \\
\text { difficult to quantify or predict. I would anticipate less } \\
\text { emphasis each day on compliance and keeping up with } \\
\text { proposed legislation and regulation. }\end{array}$ \\
\hline CEO & $\begin{array}{c}\text { Not } \\
\text { Provided }\end{array}$ & $\$ 990$ million & $\begin{array}{l}\text { We would like to see the rules concerning home loans to } \\
\text { be relaxed so that more customers will become eligible for } \\
\text { affordable housing. The new standards established in } \\
\text { Dodd-Frank were supposed to make it easier for applicants } \\
\text { to qualify for a home loan. Quite to the contrary, the new } \\
\text { standards made it less likely that an applicant will } \\
\text { qualify. In addition, it made the process more time } \\
\text { consuming and costly to the customer. Our time usage } \\
\text { would change in that we would spend more time serving } \\
\text { our customer base and reacting to their needs and less time } \\
\text { worrying about compliance. }\end{array}$ \\
\hline CEO & 35 & $\$ 425$ million & $\begin{array}{l}\text { Relief from Doff-Frank would allow us to devote more } \\
\text { time and resources to, once again, serving our customers } \\
\text { and our communities. Currently the intensified cost and } \\
\text { time required to comply with Dodd-Frank has altered the } \\
\text { way a community bank functions. Significant increases in } \\
\text { compliance cost, resulting from Dodd-Frank, are either } \\
\text { passed on to our customers or realized in reduced profit for }\end{array}$ \\
\hline
\end{tabular}




\begin{tabular}{|c|c|c|c|}
\hline & & & $\begin{array}{l}\text { bank ownership. If the later, the reduced profitability } \\
\text { makes current bank ownership question their investment } \\
\text { and ultimately the future of community banking as we } \\
\text { know it today. } \\
\text { In addition to the increased cost and frustration of } \\
\text { compliance, Dodd Frank has placed an undue burden on } \\
\text { our lending practices. We as community bankers know our } \\
\text { customers and the needs of our customers. We can, and } \\
\text { do, make prudent lending decisions that not only create } \\
\text { profits for the bank, but just as importantly provides a } \\
\text { source of financing for the needs of small business, } \\
\text { creating jobs and vitality for small town } \\
\text { America. Without Community Banks this particular } \\
\text { segment of our country is overlooked and } \\
\text { unserved. Dodd-Frank has significantly hampered our } \\
\text { ability to serve our customers! }\end{array}$ \\
\hline $\begin{array}{l}\text { Compliance } \\
\text { Officer/SVP }\end{array}$ & 22 & $\$ 190$ million & $\begin{array}{l}\text { As a community banker, I have more than one "hat." The } \\
\text { reduction of Dodd Frank compliance would allow me } \\
\text { more time to focus on other "hats" I wear. I would add that } \\
\text { some of Dodd Frank was needed, but not all. Relief from } \\
\text { some of the Consumer Real Estate burden (TRID) would } \\
\text { be nice. }\end{array}$ \\
\hline $\begin{array}{c}\text { Credit } \\
\text { Manager/VP }\end{array}$ & 14 & $\$ 300$ million & $\begin{array}{l}\text { Day to day activities would become more efficient. We } \\
\text { spend a large part of the day double and triple checking } \\
\text { consumer loans- specifically real estate secured loans. } \\
\text { With the implementation of Integrated Disclosures came a } \\
\text { host of "trip wires" that even our regulators and external } \\
\text { compliance auditors can't decipher. According to them, } \\
\text { when they try, the CFPB takes months to answer if they } \\
\text { answer at all. } \\
\text { We also spend a considerable amount of time on consumer } \\
\text { loan approvals to avoid Fair Lending violations. Very few } \\
\text { customers will fit into an underwriting box. We use an } \\
\text { automated underwriting platform, but I'd estimate that } \\
\text { only } 10 \% \text { of our applicants meet every qualification. } \\
\text { Sometimes, the mitigation process for underwriting } \\
\text { exceptions takes more time and research than a } \$ 1,000 \\
\text { loan is worth. } \\
\text { The new HMDA rule is troublesome. The data that is } \\
\text { going to be collected was expanded from } 23 \text { to } 48 \text { fields. } \\
\text { (The extra } 25 \text { fields actually drill out for a total of } 110 \\
\text { fields.) It is incredibly granular, and not only will be } \\
\text { collected on consumer real estate loans, but commercial } \\
\text { loans that are secured by } 1-4 \text { family properties. New data } \\
\text { collected includes: credit score, appraisal value, loan-to- } \\
\text { value, age, and property address. If the data is breached, } \\
\text { and I feel confident it will be, it will be a nightmare for } \\
\text { financial crime and identity theft. From an operations } \\
\text { stance, at the very least, procedure will be dramatically } \\
\text { altered and staff will be shifted to accommodate this }\end{array}$ \\
\hline
\end{tabular}




\begin{tabular}{|c|c|l|l|}
\hline & & & $\begin{array}{l}\text { change. It wouldn't surprise me to have to add staff due to } \\
\text { HMDA expansion. } \\
\text { Simply put, the cost of compliance for community banks is } \\
\text { enormous and a detriment to a bank's bottom line. } \\
\text { Eventually, smaller banks won't be able to keep up. }\end{array}$ \\
\hline $\begin{array}{c}\text { Mkt } \\
\text { President }\end{array}$ & $\begin{array}{c}\text { Not } \\
\text { Provided }\end{array}$ & $\$ 436$ million & $\begin{array}{l}\text { The level of disclosure requirements would dramatically } \\
\text { be reduced and our ability to meet borrowers' needs would } \\
\text { be simplified. The cost to meet reporting requirements } \\
\text { from the compliance standpoint is deeply impacting banks } \\
\text { income and in turn borrowers expense. Many banks have } \\
\text { almost eliminated home mortgage loans due to the } \\
\text { burdensome underwriting requirements and severe } \\
\text { penalties for any possible error in disclosures }\end{array}$ \\
\hline $\begin{array}{c}\text { Senior } \\
\text { Lommercial }\end{array}$ & 16 & $\$ 1.7$ billion \\
\hline Officer & & $\begin{array}{l}\text { A reduced burden of Dodd-Frank would free up } \\
\text { community bankers, like myself, to be more nimble with } \\
\text { customers and prioritizing their needs, versus prioritizing } \\
\text { compliance checklists. While regulation is important, } \\
\text { Dodd-Frank was legislation birthed out of crisis, which is } \\
\text { rarely equitable to everyone. } \\
\text { They would become less standardized and more on the } \\
\text { "know your customer" standards. Dodd-Frank has made it } \\
\text { much more difficult to tailor loans and deposit products to } \\
\text { customers because regulators will always favor } \\
\text { standardized products. A rollback of the burden of Dodd- } \\
\text { Frank, would allow me to be more responsive to customer } \\
\text { needs. }\end{array}$ \\
\hline
\end{tabular}


APPENDIX B: SURVEY \#2 RESULTS

\begin{tabular}{|c|c|c|c|}
\hline Position/Title & Years & Size & Response \\
\hline $\begin{array}{l}\text { MORTGAGE } \\
\text { LOAN } \\
\text { OFFICER }\end{array}$ & 6 & $\begin{array}{l}\text { OVER } 5 \\
\text { BILLION }\end{array}$ & $\begin{array}{l}\text { The law has not affected my day-to-day } \\
\text { activities. }\end{array}$ \\
\hline VP-CONTROLLER & 25 & $\begin{array}{l}\text { OVER } 5 \\
\text { BILLION }\end{array}$ & $\begin{array}{l}\text { The law did not have a significant impact on our } \\
\text { day-to-day activities as we maintained our } \\
\text { existing high level of controls and procedures. }\end{array}$ \\
\hline $\begin{array}{c}\text { SVP/ } \\
\text { CREDIT } \\
\text { OFFICER }\end{array}$ & 28 & $\begin{array}{l}\text { BETWEEN 1 } \\
\text { AND 5 } \\
\text { BILLION }\end{array}$ & No effect on my day-to-day activities. \\
\hline $\begin{array}{l}\text { CHIEF CREDIT AND } \\
\text { ADMINISTRATION } \\
\text { OFFICER }\end{array}$ & $20+$ & $\begin{array}{c}\text { OVER } 5 \\
\text { BILLION }\end{array}$ & $\begin{array}{l}\text { The impacts from the three bullet points outlined } \\
\text { above were very minimal to us given our asset } \\
\text { size but the change in accounting for loan } \\
\text { modifications was significant for many banks. It } \\
\text { allowed banks to make short term modifications } \\
\text { to loans from borrowers negatively impacted by } \\
\text { the pandemic and not treat those modifications } \\
\text { as TDR's if certain criteria were met. That } \\
\text { provision was critical in providing banks the } \\
\text { ability to help customers without unnecessary } \\
\text { regulatory scrutiny. Without that provision } \\
\text { many borrowers would have gone into default } \\
\text { and the negative financial impact of the } \\
\text { pandemic could have been much worse. }\end{array}$ \\
\hline $\begin{array}{l}\text { BUSINESS } \\
\text { DEVELOPMENT } \\
\text { OFFICER }\end{array}$ & 10 & $\begin{array}{c}\$ 17 \\
\text { BILLION }\end{array}$ & $\begin{array}{l}\text { As business development, this hasn't affected } \\
\text { our daily activities at all. Our goals and } \\
\text { processes remain the same; bring more business } \\
\text { to the bank. With our size, my department is } \\
\text { able to separate itself from the others and really } \\
\text { lean into what we do best. If any regulatory } \\
\text { issues arise, we rely on our leadership and } \\
\text { leading team to provide the framework on how } \\
\text { to navigate it. As of now, nothing has changed } \\
\text { for us. We currently hold } 17 \text { billion worth of } \\
\text { assets. }\end{array}$ \\
\hline CEO & 20 & $\begin{array}{l}\$ 100 \\
\text { MILLION } \\
\text { TO } \$ 500 \\
\text { MILLION }\end{array}$ & $\begin{array}{l}\text { It really hasn't affected us to this point. It hasn't } \\
\text { taken the strain off the very small community } \\
\text { banks at this point. We just broke the } \$ 100 \mathrm{MM} \\
\text { mark and the costs of compliance as a ratio to } \\
\text { our asset size is way above average. They are } \\
\text { unintentionally or maybe intentionally getting } \\
\text { rid of the banks that actually cater to small } \\
\text { businesses and customers they are trying to help. } \\
\text { I believe if they take a longer look at the rules } \\
\text { and sizes/complexities to make different tiers } \\
\text { with less regulation as the banks became smaller } \\
\text { and less complex it would have a bigger affect. }\end{array}$ \\
\hline
\end{tabular}




\begin{tabular}{|c|c|c|c|}
\hline STAFF APPRAISER & 4 & $\begin{array}{l}\text { \$1 BILLION } \\
\text { TO \$5 } \\
\text { BILLION }\end{array}$ & $\begin{array}{l}\text { As a real estate appraiser, this has affected my } \\
\text { day-to-day activities. We were seeing many } \\
\text { refinanced single-family residential (SFR) and } \\
\text { vacant land appraisal requests. Under the new } \\
\text { threshold guidelines our bank has adopted for } \\
\text { ordering appraisals, we have seen less SFR and } \\
\text { Land requests. We are not getting by with in- } \\
\text { house evaluations by the lenders under a certain } \\
\text { loan amount while demand for commercial } \\
\text { properties, new construction, etc., has increased. }\end{array}$ \\
\hline $\begin{array}{l}\text { COMMERCIAL } \\
\text { CREDIT } \\
\text { UNDERWRITER }\end{array}$ & & $\begin{array}{l}\text { OVER \$5 } \\
\text { BILLION }\end{array}$ & $\begin{array}{l}\text { My current financial institution has } \\
\text { approximately } \$ 28 \text { billion in assets. The } \\
\text { aforementioned Act eliminated supervisory } \\
\text { stress testing for institutions with less than } 100 \\
\text { billion in assets. In any case, any amount of } \\
\text { deregulation allows for new money to be } \\
\text { processed at a faster rate as various stress tests } \\
\text { are not required on existing and proposed debt. } \\
\text { As a commercial underwriter, this expedites the } \\
\text { loan underwriting process and the following } \\
\text { loan booking process. The third item mentioned } \\
\text { above (considering bank size) is logical as a } \$ 28 \\
\text { B bank should not be lumped into the same } \\
\text { category and level of scrutiny as a } \$ 2 \text { Trillion } \\
\text { institution. }\end{array}$ \\
\hline $\begin{array}{c}\text { VP } \\
\text { TRANSFORMATION }\end{array}$ & 50 & $\begin{array}{c}\text { BETWEEN } \\
500 \\
\text { MILLION } \\
\text { AND 1 } \\
\text { BILLION }\end{array}$ & It will not affect my day-to-day activities. \\
\hline $\begin{array}{c}\text { CHAIRMAN, } \\
\text { PRESIDENT AND CEO }\end{array}$ & 31 & $\begin{array}{l}\text { OVER \$5 } \\
\text { BILLION }\end{array}$ & Very little \\
\hline PRESIDENT AND CEO & 50 & $\begin{array}{l}\text { BETWEEN } \\
\$ 100 \\
\text { MILLION } \\
\$ 500 \\
\text { MILLION }\end{array}$ & $\begin{array}{l}\text { It has improved our ability to provide more } \\
\text { efficient service to our customers. }\end{array}$ \\
\hline CHIEF LENDER & 20 & $\begin{array}{l}\text { BETWEEN } \\
\text { \$1 BILLION } \\
\text { AND \$5 } \\
\text { BILLION }\end{array}$ & $\begin{array}{l}\text { As a lender, S. } 2155 \text { made consumer mortgage } \\
\text { lending easier by relaxing the Qualified } \\
\text { Mortgage rules. }\end{array}$ \\
\hline $\begin{array}{l}\text { REGIONAL MARKET } \\
\text { PRESIDENT- } \\
\text { ARKANSAS }\end{array}$ & 20 & $\begin{array}{l}\text { BETWEEN } \\
\text { \$1 BILLION } \\
\text { AND \$5 } \\
\text { BILLION }\end{array}$ & $\begin{array}{l}\text { The ability to do in-house v. full blown } \\
\text { appraisals on lower dollar loan amounts has } \\
\text { benefitted both the borrower and the bank-time } \\
\text { and money. Certain easing of reporting } \\
\text { standards/requirements on ATR have also } \\
\text { helped bank in regards to people hours tracking } \\
\text { ATR }\end{array}$ \\
\hline
\end{tabular}

